\title{
PERHITUNGAN DAN PROSEDUR PPH PASAL 4 AYAT 2 PADA PRIMER KOPERASI PEGAWAI POS (PRIMKOPPOS) TAHUN 2015
}

\author{
Putu Desy Ariani \\ Jurusan Akuntansi Program Diploma III, \\ Universitas Pendidikan Ganesha, Singaraja \\ putudesyariani@gmail.com
}

\begin{abstract}
Abstrak
Penelitian ini bertujuan untuk mengetahui Perhitungan dan Prosedur PPh Pasal 4 Ayat 2 Pada Primer Koperasi Pegawai Pos (PRIMKOPPOS) Tahun 2015. Objek dari penelitian ini adalah Perhitungan dan Prosedur PPh pasal 4 ayat 2 dan subjek penelitian ini adalah pendapatan bruto dan SHU pada Koperasi PRIMKOPPOS Tahun 2015. Jenis data yang digunakan adalah data kuantitatif. Sesuai dengan data yang diperlukan maka sumber data yang diperoleh yaitu data primer dan data sekunder. Teknik pengumpulan data yang digunakan pada penelitian ini adalah wawancara dan dokumentasi. Penelitian ini dilakukan dengan tehnik analisis Deskriptif Kuantitatif

Hasil penelitian menunjukkan bahwa perhitungan dan prosedur PPh pasal 4 ayat 2 mengenai peredaran bruto mengalami kesalahan pada proses perhitungan yang tidak sesuai dengan Undang - Undang No. 36 Tahun 2008 dan pada pembagian SHU untuk proses perhitungan sudah sesuai dengan Undang - Undang No. 36 Tahun 2008

Kata kunci : PPh Pasal 4 Ayat 2 mengenai Peredaran Bruto dan Pembagian SHU.

Abstrack

This study aims to determine the calculation and procedures Income Tax Article 4 Verse 2 on Primer Koperasi Pegawai Pos (PRIMKoPPoS) 2015 the object of this study is the calculation and procedures Income Tax Article 4, paragraph 2 and the subject of this study is gross income and SHU Coorperative PRIMKoPPoS 2015. The document used in quantitative document in accordance with the necessary document, the document obtained by the primary document and secondary document collection technique used in this study were interviews and documentation of the study conducted by analysis techniques descriptive quantitative results showed that the calculations and procedures of Income Tax Article 4, paragraph 2 of the gross turnover experienced an error in the calculation process Is not in accordance with Law No. 36 of 2008 and on the division of SHU for the calculation process is in accordance with Law No. 36 of 2008
\end{abstract}

Keyword : PPh Article 4 paragraph 2 of the gross circulation and distribution SHU. 


\section{Pendahuluan}

Untuk mewujudkan dan meningkatkan kesejahteraan masyarakat, pemerintah melaksanakan pembangunan nasional menyeluruh di segala bidang. Pembangunan tersebut berupa pembangunan secara fisik maupun material. Untuk membiayai pembangunan tersebut pemerintah harus memperhatikan sumber pembiayaannya. Sumber pembiayaan yang dimaksud adalah pemanfaatan Sumber Daya Alam (SDA) yaitu berupa minyak bumi dan gas alam. Sumber daya alam ini di olah oleh perusahaan dan diawasi oleh pemerintah. Disamping pendapatan dari pengolahan Sumber Daya Alam, pemerintah juga mendapatkan pembiayaan dari kegiatan ekspor, pendapatan devisa dari pariwisata dan sumber lainnya. Dari pengelolaan Sumber Daya Alam yang dilakukan oleh perusahaan pengelola, pemerintah memungut potongan berupa pajak.

Pajak merupakan sektor pemasukan tersebesar kas Negara, Penerimaan Negara dari sektor pajak memegang peranan yang sangat penting untuk kelangsungan Sistem Pemerintahan suatu Negara. Secara umum, pajak yang berlaku di Indonesia dapat dibedakan menjadi Pajak Pusat dan Pajak Daerah. Pajak Pusat adalah pajak- pajak yang dikelola oleh Pemerintah Pusat yang dalam hal ini sebagian dikelola oleh Direktorat Jenderal Pajak - Departemen Keuangan. Sedangkan Pajak Daerah adalah pajak- pajak yang dikelola oleh Pemerintah Daerah baik di tingkat Propinsi maupun Kabupaten/ Kota. Pajak- pajak Pusat yang dikelola oleh Direktorat Jenderal Pajak meliputi : Pajak Penghasilan (PPh), Pajak Pertambahan Nilai (PPN), Pajak Penjualan atas Barang Mewah (PPn BM), Bea Meterai, Pajak Bumi dan Bangunan (PBB), Bea Perolehan Hak Atas Tanah dan Bangunan (BPHTB) namun Pajak- pajak yang dipungut oleh Pemerintah Daerah baik Propinsi maupun Kabupaten/ Kota antara lain meliputi : Pajak Propinsi, Pajak Kabupaten/ Kota. Dari berbagai jenis pajak yang dikelola diatas khususnya mengenai pajak penghasilan merupakan pajak yang dikenakan kepada orang pribadi atau badan atas penghasilan yang diterima atau diperoleh dalam suatu Tahun pajak dan yang dimaksud dengan penghasilan adalah setiap tambahan kemampuan ekonomis yang berasal baik dari Indonesia maupun dari luar Indonesia yang dapat digunakan untuk konsumsi atau untuk menambah kekayaan dengan nama dan dalam bentuk apapun. Ada beberapa jenis- jenis pajak penghasilan seperti halnya PPh pasal 4, PPh pasal 21, PPh pasal 22, PPh pasal 23, dan PPh pasal 25. Namun pada kesempatan ini, penulis akan lebih menjelaskan mengenai Pajak Penghasilan pasal 4 ayat 2 pada perusahaan tertentu dimana Pajak Penghasilan pasal 4 ayat 2 merupakan pemotongan pajak final dikenakan kepada wajib pajak atas beberapa jenis penghasilan yang mereka dapatkan seperti kepentingan deposito, hadiah berupa lotere / undian, transaksi saham, dan lain- lain. Tarif berbeda untuk satu jenis penghasilan yang lain, seperti yang di-1... dalam Peraturan Pemerintah. Untuk itu penulis tertarik untuk mengambil penelitiaı dengan judul "Perhitungan Dan Prosedur PPh Pasal 4 Ayat 2 Pada Primer Koperasi Pegawai Pos (PRIMKOPPOS) Tahun 2015"

\section{Metodologi Penelitian}

Penelitian ini dilakukan untuk memperoleh informasi mengenai perhitungan dan prosedur PPh pasal 4 ayat 2 pada Koperasi PRIMKOPPOS Tahun 2015. Berdasarkan judul penelitian, maka penelitian ini menggunakan rancangan penelitian deskriptif, karena penelitian ini menjelaskan atau memaparkan apa yang terjadi sesungguhnya dilapangan. Selain itu data kuantitatif, yang menjadi sumber data penelitian ini adalah data primer yaitu data yang dikumpulkan secara langsung melalui wawancara seperti bertanya langsung ke pihak pajak. Selain data primer penulis menggunakan data sekunder yaitu data yang diperoleh dari dokumen dan catatan - catatan yang berkaitan dengan penelitian yang sudah ada seperti SHU dan Neraca pada PRIMKOPPOS

Teknik dalam pengumpulan data yang akan digunakan dalam memperoleh datadata tersebut adalah metode wawancara dan metode dokumentasi. Data yang sudah terkumpul akan dianalisis dengan menggunakan statistik deskriptif kuantitatif. Dari teknik analisis yang digunakan diharapkan bisa mengetahui bagaimana perhitungan dan pelaporan terhadap PPh pasal 4 ayat 2 yang dikenakan terhadap Koperasi PRIMKOPPOS. 
Adapun rancangan penelitian dalam penelitian ini pertama- tama peneliti menentukan lokasi penelitian. Penelitian ini dilakukan pada Koperasi PRIMKOPPOS (Primer Koperasi Pegawai Pos). Objek dari penelitian ini adalah Perhitungan dan Prosedur PPh pasal 4 ayat 2 dan subjek penelitian ini adalah pendapatan bruto dan SHU pada Koperasi PRIMKOPPOS Tahun 2015

Langkah selanjutnya setelelah lokasi penelitian ditentukan adalah merumuskan masalah dan dilanjutkan dengan pengumpulan data. Jenis data yang digunakan adalah data kuantitatif. Kuantitatif yaitu data yang diperoleh dalam bentuk angka- angka yang dapat dihitung, seperti pengenaan pajak terhadap Pendapatan Bruto dan SHU pada Koperasi PRIMKOPPOS Tahun 2015. Sesuai dengan data yang diperlukan maka sumber data yang diperoleh yaitu data primer dan data sekunder, data primer adalah data yang dikumpulkan secara langsung melalui wawancara seperti bertanya langsung ke pihak pajak dan data sekunder adalah data yang dikumpulkan atau diperoleh dari dokumendokumen yang diolah untuk menunjang penelitian melalui pihak- pihak lain yang ada hubungannya dengan Perhitungan dan Prosedur PPh pasal 4 ayat 2 seperti Pendapatan Bruto dan SHU Tahun 2015. Teknik pengumpulan data yang digunakan pada penelitian ini adalah wawancara dan dokumentasi. wawancara yaitu pengumpulan dengan bertanya langsung dengan pihak- pihak yang berkaitan dengan PPh pasal 4 ayat 2 dan dokumentasi yaitu pengumpulan data dengan cara mempelajari dokumen atau mencatat dokumen yang akan dijadikan data dalam penyusunan penelitian seperti meminta data Pendapatan Bruto dan SHU pada Koperasi PRIMKOPPOS Tahun 2015. Setelah data- data yang diperlukan berhasil dikumpulkan, maka langkah selanjutnya adalah penganalisisan sebe upaya dalam pemecahan atas permasalahan yang telah diuraikan sebelumnya. Penelitian ini dilakukan dengan tehnik analisis Deskriptif Kuantitatif.

\section{Hasil Dan Pembahasan}

Pembayaran pada Koperasi PRIMKOPPOS pada pajak PPh pasal 4 ayat 2 tentang PP nomor 46 dan juga tentang pajak SHU yang dibayarkan oleh ketua dari PRIMKOPPOS kepada pihak pajak. Pajak PPh pasal 4 ayat 2 merupakan pajak yang

bersifat final dan pembayaran yang dilakukan oleh pihak koperasi pada PP nomor 46 dibayarkan setiap bulan sebagai persyaratan yang ditujukan oleh pihak pajak kepada koperasi yang dihitung berdasarkan prediksi setelah pendapatan bunga ditambah pendapatan administrasi setiap bulan dikali $1 \%$ dan dihitung kembali jumlah perTahun setelah ditemukannya jumlah pendapatan keseluruhan dikali $1 \%$ dan apabila pembayaran pada koperasi setiap bulan kurang dari jumlah yang harus dibayar setiap Tahun maka akan dibayarkan kembali sebagai transaksi kurang bayar pada akhir Tahun dan pembayaran pajak SHU pada koperasi PRIMKOPPOS dihitung

berdasarkan dari pendapatan per Tahun dikurang biaya- biaya/ HPP per Tahun dan dikurangi dengan beban pajak atas pendapatan bruto lalu dikali $10 \%$.

\section{Perhitungan Pajak Penghasilan Pasal 4 ayat 2 mengenai PP nomor 46 pada Koperasi PRIMKOPPOS Tahun 2015}

Perhitungan pajak penghasilan pasal 4 ayat 2 mengenai PP nomor 46 pada koperasi PRIMKOPPOS setiap bulannya pada Tahun 2015 yang dilakukan oleh pihak koperasi tidak sesuai dengan Undang- Undang nomor 36 Tahun 2008 karena terjadi kekurangan bayar yang disebabkan karena kesalahan penjumlahan sehingga pihak koperasi harus membayar kekurangan bayar pada akhir Tahun sebesar Rp. 172. 289. Kekurangan bayar terjadi setiap bulannya seperti pada bulan januari pajak terutang yang harus dibayar adalah sebesar Rp.62.723 namun pihak koperasi hanya membayar sebesar Rp.37.282 dengan selisih pembayaran pada bulan januari sebesar Rp.25.441. Pada bulan Februari yang seharusnya membayar pajak sebesar Rp.67.582 namun pihak koperasi hanya membayar sebesar Rp.38.990 dengan selisih pembayaran pada bulan Februari sebesar Rp. 28.592. Pada bulan Maret yang seharusnya membayar pajak sebesar Rp.59.739 namun pihak koperasi hanya membayar sebesar Rp.41.489 dengan selisih pembayaran pada bulan Maret sebesar Rp. 18.250. Pada bulan Juli yang seharusnya membayar pajak sebesar Rp.67.167 namun pihak koperasi hanya membayar sebesar Rp.54.787 dengan selisih pembayaran pada bulan Juli sebesar Rp. 12.380. Pada bulan September yang seharusnya membayar pajak sebesar 
Rp.91.330 namun pihak koperasi hanya membayar sebesar Rp.52.430 dengan selisih pembayaran pada bulan September sebesar Rp. 38.900. Pada bulan oktober yang seharusnya membayar pajak sebesar Rp.81.004 namun pihak koperasi hanya membayar sebesar Rp.48.210 dengan selisih pembayaran pada bulan oktober sebesar Rp. 32.794. Pada bulan November yang seharusnya membayar pajak sebesar Rp.50.081 namun pihak koperasi hanya membayar sebesar Rp.49.081 dengan selisih pembayaran pada bulan november sebesar Rp. 1000. Pada bulan Desember yang seharusnya membayar pajak sebesar Rp.74.221 namun pihak koperasi hanya membayar sebesar Rp.59.829 dengan selisih pembayaran pada bulan desember sebesar Rp. 14.392 dan selisih tidak terdapat pada bulan April, Mei, Juni dan Agustus karena pada bulan tersebut tidak ada transaksi mengenai bunga penjualan, penjualan, dan lain-lain sehingga jumlah perhitungan pada bulan tersebut sesuai.

\section{Perhitungan Pajak Penghasilan Pasal 4 ayat 2 mengenai SHU/ PPh Final atas Deviden pada Koperasi PRIMKOPPOS Tahun 2015}

Pada pajak penghasilan pasal 4 ayat 2 mengenai SHU/ PPh Final atas Deviden pada Koperasi PRIMKOPPOS Tahun 2015 yang dimulai dengan perhitungan jumlah SHU dimana pada perhitungan SHU didapat dari pendapatan dikurang biaya/ HPP sehingga mendapatkan jumlah sebesar Rp. 39.301 .666 sebagai SHU sebelum pajak dan Rp. 38.544.207 setelah dikurang dengan pajak terutang atas peredaran bruto sebesar Rp. 757.459.dengan diketahuinya besaran SHU pada Tahun 2015 maka selanjutnya akan dilakukan perhitungan pembagian SHU sesuai dengan RAT Tahun sebelumnya dimana pada perhitungan pembagian SHU yang dibagikan kepada anggota koperasi hanya jasa usaha sebesar Rp. 11.563.262 dan jasa simpanan sebesar Rp. 9.636.052 sehingga total pembagian SHU bruto sebesar Rp. 21.199.314 X 10\% dan didapat pajak terutang atas SHU/ PPh final atas Deviden pada koperasi PRIMKOPPOS pada Tahun 2015 sebesar Rp. 2.119.931.

\section{Prosedur Pembayaran Pajak Penghasilan Pasal 4 ayat 2 mengenai Peredaran Bruto PP nomor 46}

Langkah- langkah yang dilakukan untuk pembayaran pajak penghasilan pasal 4 ayat 2 mengenai Peredaran Bruto PP nomor 46 pada PRIMKOPPOS yang dimulai dari perhitungan pajak terutang atas Peredaran Bruto oleh pihak koperasi dan setelah mengetahui besar pajak terutang selanjutnya pihak koperasi menuju loket Kantor Pos untuk menyetor resi bulan lalu untuk dilakukannya pencatatan masa pajak dan jumlah pajak oleh petugas loket, setelah dilakukan pencatatan lalu diserahkan sejumlah uang yang tertera pada jumlah pajak terutang yang harus dibayarkan oleh pihak koperasi setelah itu petugas loket mencetak 2 bukti pembayaran berbentuk resi, resi pertama diserahkan kepada kantor pelayanan pajak lalu pada kantor pelayanan pajak melakukan pengecekkan kelengkapan pembayaran pajak, apabila sudah lengkap resi tersebut disimpan dan apabila tidak lengkap maka pihak pajak akan memberitahu pihak koperasi untuk melengkapi kekurangan tersebut dengan membayar kembali kekurangan bayar, dan resi kedua disimpan oleh pihak koperasi sebagai arsip.

\section{Prosedur Pembayaran Pajak Penghasilan Pasal 4 ayat 2 mengenai SHU/ PPh Final atas Deviden}

Langkah- langkah pada pembayaran pajak penghasilan pasal 4 ayat 2 mengenai SHU dimulai dari perhitungan SHU yang sudah dipotong sebesar 10\% dan setelah itu dilakukan pengisian SSP rangkap 5 (lima). SSP dengan nomor 1,3,5 digunakan sebagai arsip pada koperasi PRIMKOPPOS dan SSP dengan nomor 2 digunakan sebagai laporan kepada KPP untuk dilakukan pengecekan kelengkapan pembayaran pajak, apabila sudah lengkap akan disimpan sebagai arsip namun apabila tidak lengkap pihak pajak akan memberitahu pihak koperasi untuk melengkapi kekurangan tersebut dan SSP dengan nomor 4 digunakan sebagai pelaporan pada Kantor Pos dimana tempat PRIMKOPPOS didirikan sebagai bukti bahwa PRIMKOPPOS sudah membayar pajak. 


\section{Penutup}

\subsection{Simpulan}

Dari seluruh pembahasan yang telah diuraikan, maka penulis dapat menyimpulkan hal-hal sebagai berikut: (1) Pajak Penghasilan pasal 4 ayat 2 pada Koperasi PRIMKOPPOS yang terdiri dari Peredaran Bruto dan pembagian Deviden/ SHU. (2) Pajak mengenai peredaran bruto mengalami ketidak sesuaian perhitungan yang dilakukan oleh pihak koperasi dengan perhitungan Undang-Undang nomor 36 Tahun 2008 sehingga pihak koperasi mengalami kekurangan bayar pajak dan kekurangan bayar tersebut dilunasi pada akhir Tahun. (3) Pajak mengenai pembagian Deviden/SHU sesuai dengan perhitungan Undang-Undang nomor 36 Tahun 2008 sehingga pihak koperasi tidak perlu melakukan pembayaran pajak mengenai pajak kurang bayar.

\subsection{Saran}

Dari seluruh pembahasan yang telah diuraikan maka penulis akan memberikan saran mengenai perhitungan yang dilakukan pada pajak atas peredaran Bruto agar pihak koperasi menghitung jumlah Peredaran Bruto sesuai dengan Undang-Undang nomor 36 Tahun 2008 sehingga pihak Koperasi tidak perlu mendapat surat pemberitahuan untuk melunasi kekurangan bayar mengenai pajak Peredaran Bruto.

\section{DAFTAR PUSTAKA}

Admin. 2012. "Pengertian Pajak Menurut Ahli". Tersedia pada http://ilmuakuntansi.web.id/pengertian-pajak-menurut-ahli/

Agoes, S. 2013. "Akuntansi Perpajakan”. Jakarta Selatan : Salemba Empat

Aspek Perpajakan Sesuai Peraturan Pemerintah No. 46 tahun 2013 tentang peredaran bruto, 2013. Kementrian Keuangan Republik Indonesia Direktorat Jendral Pajak Kantor Wilayah Bali

Blogspot. 2009. "Jenis dan Macam Pajak di Indonesia". Tersedia pada http://pelayananpajak.blogspot.co.id/2009/08/jenis-dan-macam-pajak-di-indonesia.html

Mahendra, Y, D, M. 2014. "Perhitungan Dan Pelaporan Pph Pasal 21 Atas Gaji Pegawai Negeri Sipil Bagian PROPAM (Provisi Pengamanan) Pada Polres Buleleng”. Tugas akhir (tidak diterbitkan). Jurusan Akuntansi Program Diploma III, Universitas Pendidikan Ganesha Singaraja.

Mardiasmo. 2011. "Perpajakan". Yogyakarta : C. V ANDI OFFSET.

Nasikhudin. 2015. "Akuntansi PPh Pasal 4 ayat (2)". Tersedia pada https://nasikhudinisme.com/2015/01/04/akuntansi-pph-pasal-4-ayat-2/

Pudyatmoko, Y. S. 2009. "Pengantar Hukum Pajak". Yogyakarta : C. V ANDI OFFSET.

Supriyanto, E. 2012. "Akuntansi Perpajakan”. Yogyakarta : Graha IImu

Wahyudi, D. 2011. "PPh Final Atas Dividen". Tersedia pada http://dudiwahyudi.com/pajak/pajak-penghasilan/pph-final-atas-dividen.html

Wibawa, F. A. dkk. 2015. "Pajak Penghasilan (PPh) Pasal 4 ayat 2 (PPh yang bersifat Final)". Makalah disajikan dalam Memenuhi Tugas Presentasi Mata Kuliah Perpajakan. Fakultas Keguruan dan IImu Pendidikan, Universitas Muhammadiyah Metro, Jakarta, 27 April 2015.

Wikipedia. 2016. "Syarat pemungutan pajak". Tersedia pada https://id.wikipedia.org/wiki/Pajak\#Syarat pemungutan pajak

Wirayanthi, D, P. 2014. "Sistem Perhitungan Dan Pelaporan Pajak Ukm Menurut Pp Nomor 46 Tahun 2013 Dan Dampaknya Bagi Koperasi Simpan Pinjam (KSP) Bali Nasional Akuntan (BNA) Sukasada". Tugas akhir (tidak diterbitkan). Jurusan Akuntansi Program 
Vol. 8 No.1. JULI 2017

p-ISSN: 2338-6177

Diploma III, Universitas Pendidikan Ganesha Singaraja 